\title{
Marriage Squeeze Among Highly Educated: Living Arrange- ments of Young Highly Educated Women in Europe ${ }^{1}$
}

\author{
Dana Hamplová ${ }^{2}$ \\ Institute of Sociology, Czech Academy of Sciences, Prague
}

\begin{abstract}
Marriage Squeeze Among Highly Educated: Living Arrangements of Young Highly Educated Women in Europe. This paper examines the role of occupational resources (field of occupation, socio-economic status, and income) in the odds of having a highly educated partner, having a partner with lower education, and staying single. The analysis of the EUSILC 2013 data demonstrate that women with better jobs and higher incomes have higher odds of living in a homogamous union with a highly educated partner. The data also show that if high resource women do not live with highly educated men, they are less likely to marry down compared to women with fewer resources and are more likely to stay single. Furthermore, the analysis demonstrates that women working in female-dominated professions are more likely to marry down and that the effect of the field cannot be explained by fewer personal resources. We also tested the idea that the link between individual resources and living arrangements is moderated by the female employment rate. We demonstrate that women are more likely to partner down in countries with higher female labor force participation. However, this tendency does not hold for high-income women.

Sociológia 2020, Vol. 52 (No. 6: 599-623)

https://doi.org/10.31577/sociologia.2020.52.6.25
\end{abstract}

Key words: Assortative mating; homogamy; gender gap; education

More than two decades ago, the traditional gender gap in higher education has been reversed in most developed countries. More women than men now obtain a tertiary level degree (DiPrete 2013; Van Bavel 2012). As demonstrated in Figure 1, by the mid-1990s, women outnumbered men among the tertiary educated in most European countries. At the end of the first decade of the $21^{\text {st }}$ century, there was over 20 percent more female than male graduates. Consequently, marriage markets for highly educated individuals changed dramatically. Indeed, there is growing empirical evidence that highly educated women from younger generations are increasingly likely to marry a man with lower education (Esteve et al. 2012; Grow - Van Bavel 2015; Van Bavel 2012).

Despite the evidence of growing female hypogamy, relatively little is known about who partners down, who partners with a highly educated man, and who stays single. Thus, this paper contributes to the existing scholarship on assortative mating by exploring the link between occupational resources and living arrangements. In particular, we raise the question of whether these women live in a homogamous union with a highly educated man, partner down, or live single.

\footnotetext{
1 Funding: The Reversal of Gender Gap in Higher Education and the Transformation of Marriage Markets, Czech Science Foundation GA ČR 17-12099S

2 Address: Prof. PhDr. Dana Hamplová, Ph.D., Sociologický ústav AV ČR, Jilská 1, 11000 Praha 1, Czech Republic.

E-mail: dana.hamplova@soc.cas.cz
} 
In this study, we focus on highly educated women for two reasons. First, women with tertiary degrees underwent the most dramatic shift in educational attainment. Thus, they also experienced the most profound transformation of marriage markets. Second, highly educated women and their mating behavior are of major interest, as educated individuals tend to be more liberal and score higher in personality traits such as openness (Anýžová 2018). They also show lower adherence to the traditional roles of men and women. The transformation of their mating behavior and the change in partners' relative human capital might have a major impact on gender relationships in general (Klesment - Van Bavel 2015). At the same time, it is plausible to assume that as the number and significance of tertiary-educated individuals increases, it becomes more influential in shaping social trends. Moreover, the college and non-college divide is the most salient educational boundary in the $21^{\mathrm{st}}$ century (Permanyer et al. 2019).

Furthermore, our study has a strong comparative dimension. We assume that the choice between homogamy, hypogamy, or singleness is linked not only to the individual level characteristics but also to the macro-level conditions that determine the benefits and costs of individual's choices. Even though all marriage markets are governed by the same general principles (e.g. individuals with more resources are more successful), the specific conditions and the value of different resources might vary across societies. In particular, we are interested in the role of female employment rates as employment patterns determine to a large extent the value of education.

The empirical part analyzes the stock of existing unions from the EU-SILC data from 2013. Arguably, existing unions provide a more complete picture of assortative mating principles than newly formed unions. Focus on the existing unions reflects the fact that the overall distance between social groups is reflected not only by the rate of intermarriage but also by the assortative dissolution of unions (Hamplová - Le Bourdais 2008; Hou - Myles 2007; Schwartz Mare 2005; Šprocha - Džambazovič 2020). Moreover, focus on the existing unions is important if we are interested in social inequality because they provide a better indication of the number of resources available in the existing households (Schwartz - Mare 2005).

Finally, it must be noted that the paper uses the term 'marriage' for simplicity. All intimate co-residential unions are considered, including unmarried cohabitations.

\section{Theoretical framework}

\section{Educational assortative mating}

In the $20^{\text {th }}$ century, education has become an important dimension of the mating behavior and the educational similarity between spouses has been growing, 
particularly in the second half of the century (Blossfeld 2009; Hamplová 2009; Mare 1991; Monaghan 2015; Schwartz - Mare 2005). The rising levels of educational homogamy are usually explained by two mechanisms. First, as women massively entered the labor market, their earning potential became more important for marriage than their domestic skills (Blossfeld - Timm 2003; Monaghan 2015; Oppenheimer 1994). Thus, highly educated men became increasingly less likely to partner with women with lower education and lower earning potential. Second, values, tastes, cultural consumption, and lifestyles became more closely linked to education. As individuals tend to interact with those who are similar to themselves and as education has become a major determinant of lifestyle and values, an academic degree became a more important dimension of a marital choice (Blossfeld 2009; DiMaggio - Mohr 1985; McPherson et al. 2001). Moreover, education became more important for labor market outcomes, such as income or security of employment, and many nonmarket outcomes, such as wellbeing (Permanyer et al. 2019). Thus, it is a key indicator and predictor of future lifestyles and life chances. At the same time, the role of other characteristics such as religion, race, or class origin in the mating choice has been weakening (Rosenfeld 2008). The tendency to select a partner with the same education was particularly strong among individuals with the highest (and lowest) levels of education, which suggests that high-resource individuals were increasingly less likely to accept a lower-resource partner (Schwartz - Mare 2005).

In the absence of homogamy, male hypogamy (i.e., the man has a higher status than the woman) has traditionally been more common than female hypogamy (i.e., the woman has the higher status). Such a pattern corresponded to the traditional division of labor and the prevalent norm of the male breadwinner family. In contrast, the female status-dominated relationships were often viewed as a deviation from social norms and expectations. However, despite the non-normativity of female hypogamy, the growing female advantage in higher education implies that an increasing number of highly educated women are not able to partner with a man who has the same education (De Hauw Van Bavel 2015; Esteve et al. 2012). Indeed, using data from 56 countries, Esteve et al. (2012) provide comprehensive evidence that female hypogamy is growing and that the couples in which the woman achieved higher education than the man are more common than couples in which the man obtained a higher degree in the majority of these countries. De Hauw et al. (2017) demonstrated similar trends in European countries. Among cohorts born in $1970-$ 1979 , female hypogamy was more common than hypergamy in 19 out of 28 countries. 
Figure 1: Percentage of graduates from tertiary education who are female $(\%)$

80,0

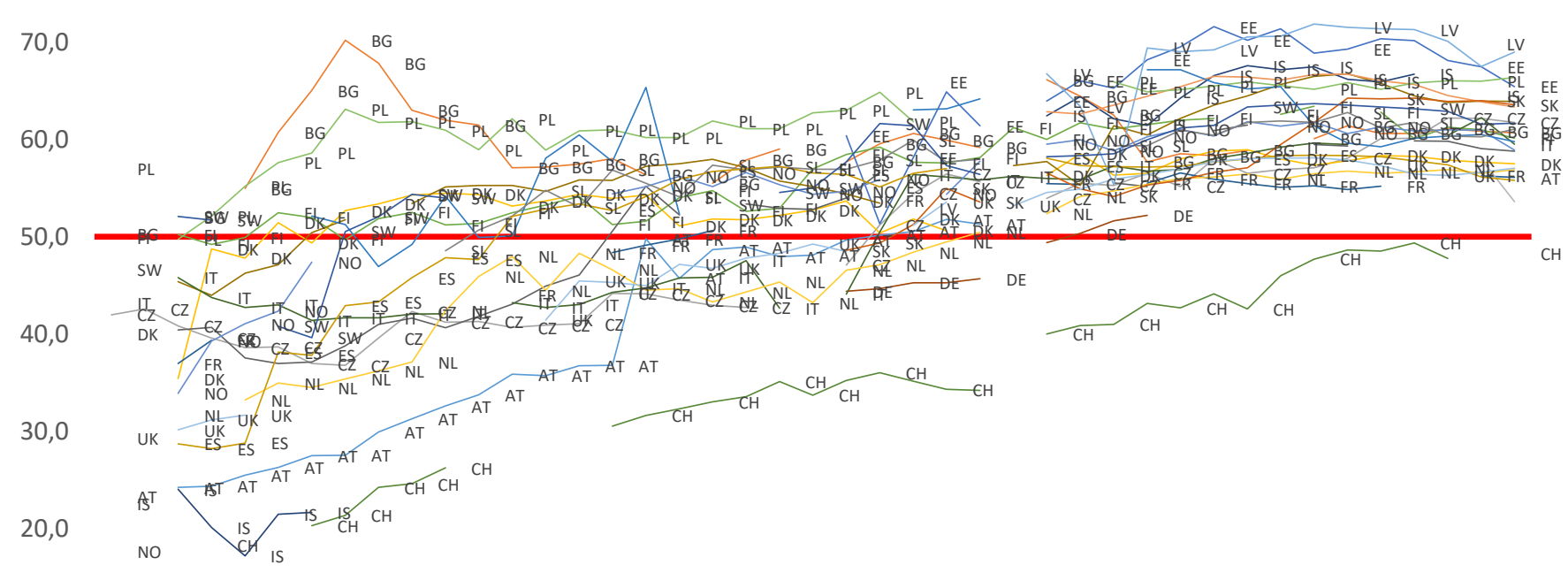

10,0

0,0

$\begin{array}{lllllllll}1971 & 1976 & 1981 & 1986 & 1991 & 1996 & 2001 & 2006 & 2011\end{array}$

Source: http://data.uis.unesco.org/\#, downloaded August 18 ${ }^{\text {th }}, 2020$ 
Some authors advanced the hypothesis that the increase in female hypogamy is a sign of declining aversion to female-status-dominated relationships (Klesment - Van Bavel 2017). Nevertheless, analyses of divorce risks suggest that growing female hypogamy might be a consequence of lower availability of alternatives rather than a sign of changing preferences (Grow et al. 2017). This would mean that the increasing tendency to marry down might be explained by the lack of alternatives and increasing competition among highly educated women rather than by the change of attitudes.

Our approach is built on the assumption that highly educated women still prefer a highly educated partner. First, 'like is attracted to like' and homophily is a dominant mechanism in partner's selection in general (McPherson et al. 2001). Men and women tend to select their likes particularly in characteristics that are linked to lifestyles and values, which partly applies to education. Second, education is an important determinant of income. As individuals generally prefer partners of 'better quality', more educated - and typically higherearning - partners are likely to be more desirable than low educated individuals. This general principle might be even more tenacious in the case of men as their identity is still more closely associated with labor market status. Third, even women who heavily invest in the labor market and seek a man who participates in domestic chores and childcare are likely to prefer highly educated men. Men with higher education tend to be more liberal and hold less traditional views on female and male roles. In line with this argument, there is comprehensive evidence that more educated men do more housework than their counterparts with less education (Coltrane 2000; Hamplová et al. 2019; Sullivan et al. 2014; Treas - Tai 2016). Thus, if a woman seeks a partner that is willing to take some responsibility for domestic tasks and childcare, she is more likely to find such a match among highly educated men.

\section{Marriage markets and marriage squeeze among highly educated women}

The reversal of the gender gap in higher education produced a certain type of marriage squeeze among highly educated females as more women compete for a smaller number of highly educated men. Marriage squeeze is a demographic concept that has been introduced in the 1960s. It refers to the idea that the excess of one sex over the other will leave some without partners (Akers 1967). Marriage squeeze might be produced by disproportions in absolute numbers of men and women but can arise also from differences in characteristics relevant for the selection of mates. Originally, the concept of marriage squeeze was applied to the disproportion of men and women in prime marriage ages (Akers 1967; Katrńák 2001). Nevertheless, the concept was extended to the disproportion of male and female graduates to describe education-specific marriage squeeze (Van Bavel 2012). 
As the competition for highly educated men increases, the group of highly educated women is likely to become more stratified. Some women partner with a highly educated man, others have two options. They might marry down or they can keep searching or forgo a union rather than marry a man with lower status (Van Bavel 2012). It is reasonable to assume that the choice between homogamy, hypogamy, or singleness is not random but is affected by various individual-level characteristics and macro-level conditions.

To understand the role of these characteristics, the concept of the marriage market is useful (Becker 1996). This metaphor invokes the idea that partner's choice in modern societies is conducted by free individuals who compete with each other to attract the best matches and to maximize their utility (Becker 1973, 1996; Monaghan 2015; Oppenheimer 1988). Similarly to any other market transactions, individuals of 'better quality' are able to command 'higher price' and to snare 'high-quality' partners. A range of individual characteristics might be used as trade-offs or assets to compete for the best matches at the marriage market, including personality traits, physical attractiveness or willingness and skills to contribute to housework (Gottschall et al. 2008; McClintock 2014; Šetinová - Klímová Chaloupková 2019). This paper focuses on the importance of occupational resources as they are of special interest for research on social inequality.

In particular, we are interested in three characteristics of the labor market position: income, occupational status, and the field of occupation. As for income and occupational status, the observation that more resources lead to better matches is a guiding principle of any mating market. Given the massive entry of women into the labor market, their earning potential, and financial contribution to the household became an important asset in the marriage market (Schwartz - Mare 2005). Thus, we expect that women with higher incomes are more successful in attracting a highly educated man. Woman's resources are also likely to be linked to the choice between marrying down and staying single. High-resource women have more means to forgo an undesirable union (Dykstra - Poortman 2010).

Concerning the field of occupation, we suggest that the level of feminization is of major importance. A number of studies show that the field of education is as important or might be even a better indicator of a woman's family behavior than the level of education attained (Bagavos 2010; Hoem et al. 2006; Van Bavel 2010). Three mechanisms might be at play. First, male-dominated fields tend to be linked with more resources. Given the leading principle of all marriage markets that more resources lead to a better match, it is plausible to expect that women working in typically female fields are viewed as worse matches than women from typically male fields. Thus, we would expect more homogamy among highly educated women working in male-dominated jobs. 
Second, women in male-dominated fields have more opportunities to meet their highly educated male peers. This principle would also increase the odds of homogamy among women from male fields but this increase would not be explained off by their individual resources.

Third, women in the male- and female-dominated fields might differ in their willingness to forgo a less advantageous match. There is evidence that women with different values and normative expectations self-select themselves into various occupations. For example, women with higher family orientation often prefer disciplines that require stereotypical female qualities, such as caring and interpersonal contacts (for similar arguments about the field of study see Van Bavel 2010). This means that they might be less willing to postpone a union formation in hope that they could meet a better match in the future. Moreover, entering into such fields might further socialize women into these qualities as the environment fosters gender-typical attitudes and roles (Van Bavel 2010). Consequently, women in female-dominated professions might be less willing to keep waiting and accept an available match with a man with lower education.

Built on the theoretical arguments presented above, we formulate the following hypotheses about the individual-level characteristics:

Hypothesis 1: Women with higher incomes and better jobs are more likely to live in a homogamous union with a highly educated partner than women with lower incomes and lower occupational status. This hypothesis is built on the leading principle of any mating market that individuals with more resources are able to attract better matches than those with fewer resources (Becker 1993).

Hypothesis 2: In the absence of homogamy, women with higher incomes and higher status jobs are more likely to forgo a union than women with fewer resources. Women with lower incomes and lower status jobs are more likely to partner down. Indeed, there is past evidence that women with more resources are less likely to marry down as they are able to postpone marital search and able to avoid undesirable unions (Dykstra - Poortman 2010).

Hypothesis 3: Women working in typically male fields are more likely to live in a homogamous union with a highly educated partner than women working in typically female fields. Male-dominated fields are generally linked to higher resources than female-dominated fields and higher resource individuals are able to attract better matches (Murphy - Oesch 2016).

Hypothesis 4: In the absence of homogamy, women working in the maledominated professions are more likely to forgo a union than women in female-dominated occupations. The link between female hypogamy and the field of occupation cannot be explained off by women's individual resources. As female occupations tend to be linked to more pro-family values, these women are less likely to postpone or forgo a union even if they do not meet a highly educated man (Bagavos 2010; Hoem et al. 2006). 


\section{Cross-national differences}

Finally, mating behavior and marital choices are not acts of isolated individuals but need to be considered in the institutional context of society. The patterns of who marries whom are significantly affected by structural constraints of national marriage markets (Permanyer et al. 2019). A number of studies have shown that mating patterns vary across countries (Katrnák et al. 2012) and that conditions of the local mating market affect not only who marries whom but also who remains single (De Hauw et al. 2017).

Our theoretical background is built on the assumption that occupational characteristics constitute an important resource that can be used to attract a better match on the mating market. This expectation is grounded in the fundamental condition that individuals translate their occupations into resources on the labor market. Thus, in this paper, we are particularly interested in the question of how female employment rates affect the link between occupational resources and mating. We suggest that the level of the female labor force participation can be used as a proxy for the benefits and costs of various types of unions and mating strategies. First, if women's attachment to the labor market is looser, we can assume that the role of occupational resources in the marital choice would be weaker. The mating strategies of a woman that is expected to reduce labor force participation upon starting the family are likely to differ from strategies of women who expect to continue working through various life stages. At the same time, the relative attractiveness of the woman might also be linked to the extent to which she can take advantage of her education. Thus, it is plausible to expect that the role of occupational characteristics differs according to the female employment rate. In particular, higher occupational resources might be more important in countries with higher female employment rates.

Second, under the more traditional gender role specialization (and lower female labor force participation), women are more motivated to search for men with better economic prospects who would act as the main breadwinners in the family. In other words, if women assume that the family will be - at least temporarily - dependent primarily on their husbands' resources, they might put a higher emphasis on finding a highly educated man and might be reluctant to marry down. This might increase their willingness to postpone an undesirable union and increase the odds of singleness.

Hypothesis 5: The link between individual resources and homogamy is stronger in countries with higher female labor force participation.

Hypothesis 6: The reluctance to marry down is stronger in countries with lower female labor force participation. 


\section{Data and method}

\section{Method}

This paper used the multilevel regression models to explore the factors that are linked to the odds of living in homogamous or hypogamous unions or not having a co-residential partner among highly educated women in Europe. Specifically, it adopted a sequential logit design and modeled mating processes in two steps. Our modeling strategy was built on the assumption that highly educated women prefer men with high education. Indeed, there is some evidence that highly educated women are still reluctant to lower their aspirations despite the growing 'marriage squeeze' (Skopek et al. 2010). Only if such an option is not available, they partner down or decide to forgo a union. Thus, in the first step, the analysis explored the odds of living in a homogamous union versus or all other options (i.e. partnering down or staying single). In the second step, the odds of marrying down (rather than staying single) were estimated for those who do not live in a homogamous union.

To account for the inter-dependence between observations from the same country, we adopted a multilevel mixed-effects approach in Stata 15 (meqrlogit). In such cases, the use of OLS regression would be inappropriate as the standard linear models are built on the assumption of independence between observations (Wooldridge 2009). Although such hierarchical data could be also analyzed using OLS with country dummies, such an approach does not allow for incorporating country-level variables.

\section{Data}

The paper used the EU-SILC data from 2013. Only economically active women with the completed tertiary education who were born in 1979 or later and who were at least 25 years of age at the time of the survey were selected for the analysis. In total, information on 8391 women aged 25 to 34 from 27 European countries was analyzed (Austria, Belgium, Bulgaria, the Czech Republic, Germany, Denmark, Estonia, Finland, France, Greece, Hungary, Ireland, Iceland, Italy, Latvia, Luxemburg, Lithuania, the Netherlands, Norway, Poland, Portugal, Slovenia, Slovakia, Spain, Sweden, Switzerland, and the United King$\mathrm{dom}^{3}$ ). The age bracket 25-34 was chosen for two reasons. First, by age 25, the majority of women have already finished at least the first step of tertiary education. Second, the age bracket 25 to 34 is considered to be the prime age for the formation of co-residential unions (De Hauw et al. 2017).

\footnotetext{
${ }^{3}$ No information on female employment rates in Croatia, Malta, and Serbia is available and these countries are not included in the analysis. The Romanian sample is not included due to some problems in the data (only a negligible number of Romanian women had a recorded conjugal union).
} 


\section{Dependent variable}

Two dependent variables were analyzed. In the first step, a binary variable distinguishing those who lived with a partner who has also graduated from the tertiary institution and all others was used (homogamy $=1$, otherwise $=0$ ). Afterward, only women who did not live in a homogamous union at the time of the survey were selected. In the second step, the dependent variable differentiated highly educated women who partnered down and those who were single at the time of data collection (hypergamy $=1$, singleness $=0$ ).

\section{Explanatory variables}

The EU-SILC data uses the two-digit ISCO-08 code for occupation. For each occupational group, the proportion of men was calculated (from 10,4 percent to 95,3 percent). The most feminized occupational groups (nursing, chambermaids) included around 10 percent of male workers. In contrast, the most maledominated professions (construction) included around 5 percent of female workers. Based on this information, male-dominated, female-dominated, and mixed professions were distinguished. Two measures were adopted in this paper that have a tradition in social sciences (Blau et al. 2013; Sheridan 1997). First, male and female occupations were defined as jobs in which at least 70 percent of workers belong to the respective sex (i.e., female occupation $=$ at least 70 percent of females, male occupation $=$ at least 70 percent of males). Using this distinction, around 10 percent of women worked in male-dominated occupations, 49 percent in female-dominated occupations, and 41 percent in mixed professions. Second, we adopted the definition of integrated occupations in which women constituted between 40 to 60 percent of workers (Blau et al. 2013). If we used the cut-point of 60 percent, 13 percent of women worked in male-dominated professions, 55 percent in the female/dominated, and 31 percent in mixed professions. The distinction between male-dominated, femaledominated, and mixed occupation was based on all workers in the pooled sample. It was not possible to calculate a country-specific indicator as the occupational categories are detailed and the number of respondents in each occupation was very low.

Individual-level resources were measured by three characteristics: status of occupation, a supervisory position, and income. The International SocioEconomic Index of Occupations (ISEI ${ }^{4}$ - see Ganzeboom and Treiman, 1996) was used as a proxy for the status of the occupation. It expresses the cultural and economic resources typical for each occupation.

Furthermore, we included information about whether the woman was in a supervisory position (yes $=1$, no $=0$ ). The self-employed individuals with em-

\footnotetext{
${ }^{4}$ EU-SILC contains only two-digit ISCO codes whereas ISEI is based on the four-digit ISCO codes. Thus, the original twodigit ISCO was multiplied by 100 .
} 
ployees were also included among supervisors. Even though it would be interesting to keep businesswomen as a separate category, the number of selfemployed women in the analyzed sample was very low. We estimated all models twice, once including the self-employed women and once dropping them out. The results were practically the same and we decided to keep them for the analysis to have a slightly larger sample size.

The net personal income was coded into country-specific deciles for tertiary-educated women aged 25-34. The measure expresses the relative standing of the respondent compared to her peers in the same age and educational group. A preliminary analysis of homogamy showed that the association between income and the odds of homogamy is non-linear and only women in the highest decile differ from the others. Thus, a binary measure distinguishing highincome women (those in the highest income decile $=1$, otherwise $=0$ ) is used in the first step. However, the linear measure seemed to be more appropriate for estimating the odds of hypogamy (versus staying single). The fact that only women belonging to the highest income decile differed from the rest of the population in the analysis of homogamy suggests that the observed pattern might not be explained by general income effect but rather by membership in an elite group.

At the country level, the female employment rate refers to the OECD statistics on the labor force participation of women aged 25 to 64 in 2013. We use female labor force participation for all productive ages, not only for the selected ages that were analyzed in this paper. We believe that the mating behavior is affected not only by the current situation (employment at the age of 25-34) but also by the expected returns to education in the future. For example, in some countries, women are expected to drop out of the labor market for a substantive period of time after starting the family. Thus, their and their partner's behavior might be affected by the expectation that their employment patterns would change in the future.

All models controlled for age and subjective health (being in very good health $=1$, otherwise, 0 ). The age was controlled as it is a strong predictor of union formation. Even though we used a relatively narrow age category (2534 ), it covers the prime ages for coresidential union formation. There is an important difference between younger and older women even within this age group. Subjective health was controlled as a possible confounder. Bad health is likely to affect both, union formation and employment status. At the country level, we controlled for the sex ratio in higher education, which determines the general situation of the marriage market for highly edcated women. The measure is derived from the UNESCO educational statistics. A mean sex ratio be- 
tween the years 2000 and 2013 is used ${ }^{5}$. In models predicting the odds of homogamy, the sex ratio was used as a continuous indicator. We also tested various categorical measures but we did not find any evidence for a non-linear relationship. Thus, we used the linear measure expressing the relative female advantage in education (the larger value means the higher female advantage). However, in models predicting hypogamy (versus singleness), a binary variable distinguishing countries with a larger female advantage and a lower female advantage was used. The model with a linear measure yielded large estimated values for the sex ratio with enormous confidence intervals. Moreover, an additional sensitivity analysis suggested that the estimates for the linear measure of the sex ratio were relatively unstable ${ }^{6}$. Thus, we divided the linear indicator into deciles in the first step. The inspection of the results showed that the difference was only between one-third of countries with the highest sex ratio and the others. Thus, a binary variable reflecting this difference was created.

\section{Results}

\section{Descriptive statistics}

Table 1 reports the descriptive statistics for the analytical sample. In total, we had information on 8,391 women; the mean age was 30.0 years. As for other characteristics, we observed major differences across societies. Greek young women enjoyed particularly good health (nearly 80 percent) while less than 20 percent of Lithuanian and Latvian women reported being in very good health. Using the 70 percent cut-off to define the male- and female-dominated occupations, except for Ireland, only a small proportion of young tertiary-educated women worked in male-dominated professions. The proportion of women concentrated in the female occupations was lowest in Latvia and Lithuania (less than 30 percent) as the majority of women from these countries worked in mixed occupational groups. In contrast, the proportion of women working in female-dominated occupations was highest in Greece and Italy (over 60 percent). Around 20 percent of all respondents worked in a supervisory position. Surprisingly, the proportion was particularly low in Denmark (5.7 percent). Nevertheless, even in the unrestricted sample (i.e. women of all ages and from all educational groups), only 7 percent reported a supervisory position in Denmark.

\footnotetext{
${ }^{5}$ See http://www.uis.unesco.org/DataCentre/Pages/BrowseEducation.aspx. Downloaded on January 25, 2016.

${ }^{6}$ We re-estimated the model several times. In each step, we deleted a country and compared the estimated coefficients for sex-ratio. These model provided very unstable results and the coefficients varied largely based on a specific combination of countries.
} 
Table 1: Descriptive statistics of the analytical sample

\begin{tabular}{|c|c|c|c|c|c|c|c|c|}
\hline & $\begin{array}{l}\text { Age } \\
\text { mean }\end{array}$ & $\begin{array}{l}\text { Health } \\
\%\end{array}$ & $\begin{array}{l}\text { Occupation } \\
\text { male (\%) }\end{array}$ & female $(\%)$ & $\begin{array}{l}\text { Supervisor } \\
(\%)\end{array}$ & $\begin{array}{l}\text { ISEI } \\
\text { mean }\end{array}$ & $\begin{array}{l}\text { Sex ratio } \\
\text { in education }\end{array}$ & $\begin{array}{l}\text { Female } \\
\text { employment }\end{array}$ \\
\hline Austria & 30.0 & 64.4 & 9.4 & 43.8 & 46.3 & 63.7 & 0.5 & 80.5 \\
\hline Belgium & 30.1 & 49.4 & 10.5 & 56.0 & 21.6 & 61.2 & 0.5 & 74.0 \\
\hline Bulgaria & 29.4 & 45.4 & 11.2 & 34.9 & 19.7 & 58.6 & 0.6 & 71.5 \\
\hline Czech R. & 30.4 & 55.9 & 11.9 & 47.0 & 18.8 & 64.1 & 0.5 & 80.9 \\
\hline Denmark & 29.9 & 36.8 & 7.6 & 54.7 & 5.7 & 62.4 & 0.5 & 75.5 \\
\hline Estonia & 29.4 & 29.3 & 12.5 & 36.6 & 19.7 & 66.7 & 0.6 & 78.6 \\
\hline Finland & 30.1 & 38.0 & 12.7 & 53.3 & 12.7 & 60.0 & 0.5 & 79.0 \\
\hline France & 30.1 & 40.8 & 11.4 & 51.3 & 39.5 & 60.5 & 0.6 & 76.0 \\
\hline Germany & 30.3 & 42.7 & 10.2 & 51.7 & 20.8 & 59.1 & 0.6 & 51.4 \\
\hline Greece & 30.0 & 79.4 & 7.6 & 62.9 & 10.7 & 55.2 & 0.5 & 61.2 \\
\hline Hungary & 29.9 & 40.9 & 8.9 & 40.4 & 11.3 & 61.5 & 0.6 & 78.1 \\
\hline Ireland & 30.8 & 58.0 & 32.5 & 38.9 & 26.9 & 49.4 & 0.5 & 76.3 \\
\hline Iceland & 29.7 & 55.6 & 9.1 & 55.6 & 54.6 & 58.7 & 0.6 & 70.0 \\
\hline Italy & 30.4 & 27.5 & 10.1 & 61.6 & 17.2 & 54.1 & 0.6 & 65.6 \\
\hline Latvia & 29.9 & 19.2 & 8.4 & 27.5 & 14.4 & 62.2 & 0.6 & 82.3 \\
\hline Lithuania & 29.5 & 17.5 & 12.8 & 29.5 & 11.1 & 60.7 & 0.6 & 58.0 \\
\hline Luxembourg & 30.2 & 44.7 & 4.8 & 49.6 & 17.5 & 65.3 & 0.5 & 76.1 \\
\hline Netherlands & 30.2 & 37.7 & 6.9 & 41.3 & 15.8 & 66.4 & 0.5 & 75.5 \\
\hline Norway & 29.5 & 43.2 & 11.7 & 56.4 & 16.2 & 64.8 & 0.6 & 79.4 \\
\hline Poland & 29.7 & 37.7 & 7.4 & 46.6 & 17.9 & 58.3 & 0.6 & 82.6 \\
\hline Portugal & 29.9 & 25.2 & 9.2 & 54.2 & 33.6 & 63.0 & 0.6 & 81.6 \\
\hline Slovakia & 31.0 & 43.8 & 8.2 & 45.7 & 21.5 & 62.8 & 0.6 & 71.2 \\
\hline Slovenia & 29.5 & 41.0 & 3.1 & 44.8 & 9.7 & 58.8 & 0.6 & 72.2 \\
\hline Spain & 29.9 & 34.3 & 7.8 & 56.8 & 19.1 & 52.7 & 0.5 & 82.7 \\
\hline Sweden & 30.2 & 46.0 & 16.0 & 44.9 & 11.8 & 63.2 & 0.6 & 79.3 \\
\hline Switzerland & 30.0 & 53.5 & 12.8 & 52.0 & 20.5 & 65.0 & 0.5 & 69.6 \\
\hline UK & 30.1 & 60.3 & 11.0 & 48.4 & 33.8 & 59.6 & 0.6 & 75.2 \\
\hline Total & 30.0 & 42.5 & 10.5 & 48.4 & 20.7 & 59.7 & & \\
\hline
\end{tabular}

Source: SILC 2013, N (individuals) $=8391, \mathrm{~N}$ (countries) $=27$
Source sex ratio in education: UNESCO; Source female employment: OECD 
Table 2 reports the proportion of women living in homogamous and hypogamous unions and staying single. The highest share of homogamous unions was found in Switzerland, Ireland, and the United Kingdom (around a half). In contrast, highly educated women from Southern Europe, Bulgaria, and Slovakia were least likely to live with a man with a tertiary degree. These descriptive statistics suggest that the relatively low levels of homogamy in these countries cannot be contributed to the willingness to marry down. It was rather a consequence of the high proportion of single women in this age group. Thus, in Italy, Greece, and Portugal, around 60 percent of women aged 25-34 were not living in a co-residential union. It might reflect the fact that alternative family norms (including unmarried cohabitations) are less accepted in these countries and female hypogamy might be more stigmatized in these countries.

Table 2: Proportion of tertiary-educated women in living in homogamous unions, hypogamous unions, and staying single (\%)

\begin{tabular}{|c|c|c|c|}
\hline & Homogamy & Hypogamy & Single \\
\hline Austria & 29.6 & 21.6 & 48.8 \\
\hline Belgium & 43.4 & 30.8 & 25.7 \\
\hline Bulgaria & 19.0 & 27.7 & 53.4 \\
\hline Switzerland & 49.7 & 21.4 & 28.9 \\
\hline Czech Republic & 39.8 & 34.5 & 25.7 \\
\hline Germany & 37.7 & 20.4 & 42.0 \\
\hline Denmark & 35.1 & 22.1 & 42.8 \\
\hline Estonia & 33.7 & 32.8 & 33.5 \\
\hline Greece & 21.3 & 20.2 & 58.5 \\
\hline Spain & 27.2 & 22.6 & 50.2 \\
\hline Finland & 41.3 & 25.9 & 32.9 \\
\hline France & 46.2 & 29.3 & 24.5 \\
\hline Hungary & 29.4 & 21.4 & 49.2 \\
\hline Ireland & 52.4 & 17.3 & 30.2 \\
\hline Iceland & 26.2 & 33.3 & 40.5 \\
\hline Italy & 20.9 & 17.5 & 61.6 \\
\hline Latvia & 42.8 & 18.5 & 38.8 \\
\hline Luxembourg & 43.7 & 19.8 & 36.5 \\
\hline Lithuania & 27.6 & 32.3 & 40.1 \\
\hline Netherlands & 31.2 & 20.7 & 48.1 \\
\hline Norway & 35.0 & 18.9 & 46.2 \\
\hline Poland & 37.6 & 25.2 & 37.3 \\
\hline Portugal & 22.8 & 19.2 & 58.0 \\
\hline Sweden & 37.0 & 22.6 & 40.4 \\
\hline Slovenia & 28.8 & 34.9 & 36.3 \\
\hline Slovakia & 23.6 & 26.3 & 50.1 \\
\hline United Kingdom & 50.1 & 24.4 & 25.4 \\
\hline Total & 37.4 & 23.9 & 38.7 \\
\hline
\end{tabular}

Source: SILC 2013, N (individuals) $=8391, \mathrm{~N}$ (countries) $=27$ 


\section{Regression analysis - Individual-level characteristics}

The left-hand side of Table 3 reports the estimated odds ratios from multilevel logistic regressions with the dependent variable homogamy (v. hypogamy or singleness). The right-hand side of the same table shows the estimated odds ratios of hypogamy (versus singleness) for a sub-sample of women who did not live in a homogamous relationship.

In the first step, models included information on woman's resources (woman's income, ISEI of her job, and whether she held a supervisory position or not) and all control variables (age, subjective health, the sex ratio in higher education in the country). Hypothesis 1 was derived from the fundamental premise of the marriage market theory that more resources mean higher odds of having a high-quality partner. It predicted that women with more occupational resources would be more likely to live in a homogamous union than those with lower resources. This hypothesis was fully corroborated by Model 1A. As this model demonstrates, the more resources the woman had, the higher were her odds to find a highly educated partner. Women in the highest income decile had approximately 25 percent higher odds of living in a homogamous union than women with lower incomes. If belonging to the highest income decile signals elite membership, our findings demonstrate that more elite women were more likely to attract a highly educated partner. Similarly, supervisors had nearly 20 percent higher odds to partner with a highly educated man than those without a supervisory position. Furthermore, the socioeconomic status of the job had also an independent positive effect on homogamy among highly educated women.

Furthermore, we hypothesized that women with higher incomes and higher status jobs were more likely to forgo a union than women with fewer resources if they did not find a highly educated partner. However, Hypothesis 2 was only partly supported by our data (Model 1B). As expected, women in the highest income decile incomes were less likely to partner down. However, no significant relationship between the socio-economic status of the job or a supervisory position and educational hypogamy was found (Model 1B). This finding suggests that more resources are not necessarily linked to avoidance of hypogamy. It was rather the group of elite women (highest income) that avoided partnering down.

Models $2 \mathrm{~A} / \mathrm{B}$ and $3 \mathrm{~A} / \mathrm{B}$ tested the differences across the fields of occupation. Models 2A and 2B used the 70 percent cut-off point. This means, that male- and female-dominated occupations were defined as those with at least 70 percent of the respective sex. Models 3A and 3B used the 60 percent cut-off point defining male- and female-dominated occupations as those with at least 60 percent of the given sex. As predicted in Hypothesis 3, women working in the male-dominated occupations were more likely to have a highly educated 
Table 3: The estimated odds of homogamy among highly educated women (versus hypogamy or singleness) and the estimated odds of hypogamy among highly educated women (versus singleness)

\begin{tabular}{|c|c|c|c|c|c|c|c|c|c|c|}
\hline \multirow[b]{2}{*}{ Individual level } & \multicolumn{5}{|c|}{ Homogamy (versus hypogamy or singleness) } & \multicolumn{5}{|c|}{ Hypogamy (versus singleness) } \\
\hline & Model 1A & Model 2A & Model 3A & Model 4A & Model 5A & Model 1B & Model 2B & Model 3B & Model 4B & Model 5B \\
\hline Age & $1.135^{* *}$ & $1.148^{* *}$ & $1.146^{* *}$ & $1.135^{* *}$ & $1.135^{* *}$ & $1.228 * *$ & $1.220 * *$ & $1.221 * *$ & $1.230 * *$ & $1.230^{* * *}$ \\
\hline Very good health & 1.042 & 1.075 & 1.072 & 1.043 & 1.043 & $0.877^{*}$ & $0.858^{*}$ & $0.859 *$ & $0.873 *$ & $0.873 *$ \\
\hline ISEI & $1.015^{* *}$ & & & $1.015^{* *}$ & $1.015^{* *}$ & 0.998 & & & 0.999 & 0.999 \\
\hline Supervisor & $1.216^{* *}$ & & & $1.209 * *$ & $1.200^{* *}$ & 1.035 & & & 1.068 & 1.079 \\
\hline Income - highest decile & $1.236^{*}$ & & & $1.228^{*}$ & $1.220^{*}$ & & & & & \\
\hline Income - decile (linear) & & & & & & $0.934 * *$ & & & $0.935 * *$ & $0.935 * *$ \\
\hline \multicolumn{11}{|l|}{ Gender occup (comp. female) } \\
\hline Male occupations (70\%) & & $1.280 * *$ & & 1.112 & & & $0.592 * *$ & & $0.613 * *$ & \\
\hline Mixed occupations (70\%) & & 1.039 & & 1.019 & & & $0.857 *$ & & $0.861 *$ & \\
\hline Male occupations (60\%) & & & $1.338 * *$ & & 1.118 & & & $0.660 * *$ & & $0.679 * *$ \\
\hline Mixed occupations (60\%) & & & $1.145^{*}$ & & 1.047 & & & $0.860^{*}$ & & 0.886 \\
\hline \multicolumn{11}{|l|}{ Country level } \\
\hline Sex ratio in education (linear) & 0.187 & 0.173 & 0.154 & 0.184 & 0.178 & & & & & \\
\hline Sex ratio in education (binary) & & & & & & 1.398 & 1.403 & 1.413 & 1.413 & 1.418 \\
\hline BIC & 10205.6 & 10335.6 & 10326.3 & 10222.0 & 10221.2 & 6764.3 & 6765.5 & 6769.8 & 6760.2 & 6765.2 \\
\hline AIC & 10149.3 & 10286.3 & 10277.1 & 10151.6 & 10150.9 & 6711.4 & 6719.2 & 6723.6 & 6694.1 & 6699.1 \\
\hline Log likelihood & -5066.7 & -5136.1 & -5131.6 & -5065.8 & -5065.4 & -3347.7 & -3352.6 & -3354.8 & -3337.1 & -3339.6 \\
\hline $\mathbf{N}$ & 8391 & 8391 & 8391 & 8391 & 8391 & 5449 & 5449 & 5449 & 5449 & 5449 \\
\hline
\end{tabular}

Source: SILC 2013, N (countries) $=27$ 
partner than women from female-dominated professions. This conclusion held irrespective of whether we used the 70 or 60 percent cut-off (see Model 2A and $3 \mathrm{~A})$. However using a less strict definition of male- and female-dominated occupations (i.e. 60 percent) suggested that even women from mixed occupations were more likely to partner with highly educated men than women from female professions. The difference between mixed- and female-dominated professions was however not significant if the 70 percent cut-off was used.

Nevertheless, as demonstrated by Model 4A and 5A, the differences between male- and female-dominated fields were fully explained by income and other resources. When women's occupational resources were integrated into the model, the differences across fields ceased to be significant. This suggests that the relative advantage of women from male-dominated fields were linked to their individual resources, not to better meeting opportunities.

In Hypothesis 4, we expected that, in the absence of homogamy, women from female-dominated fields would be less likely to forgo a union than women from male-dominated fields. Again, our data fully corroborated this prediction. As Model 2B and 3B in Table 3 demonstrated, among women who did not live with a highly educated partner, women from male-dominated occupations had nearly 40 percent lower odds to partner down than women from female professions. Irrespective of the definition of female-dominated jobs (60 or 70 percent cut-off point), our data suggest that even women from the mixed professions were less likely to partner down than those from female-dominated jobs.

Hypothesis 4 also specified that the link between female hypogamy and the field of occupation cannot be explained off by women's individual resources. This was corroborated by our data. Importantly, integrating income into the model did not change the link between the field of occupation and hypogamy. Even if a woman's income was controlled for, the estimates for the field stayed significant and the coefficients stayed nearly unchanged.

\section{Regression analysis - Female labor force participation}

Tables 4 and 5 include information about the female labor force participation in the given country. First of all, our data showed that in countries with higher female labor force participation, the odds of homogamy were higher. One percent increase in the labor force participation raised the odds of homogamy by 4 percent (see Model 1 in Table 4). Table 4 tests Hypothesis 5 predicting that the link between individual resources and homogamy is stronger in countries with higher female labor force participation. To test this prediction, a set of models with the interaction between the country's female labor force participation and woman's occupational resources were included. As the field of occupation did not exert any independent effect on the odds of homogamy beyond personal resources (see Models 4A and $5 \mathrm{~A}$ in Table 3), it is not included. 
Table 4: The estimated odds of homogamy among highly educated women, cross-level interactions

\begin{tabular}{|c|c|c|c|c|c|c|c|}
\hline Individual level & Model 1 & Model 2 & Model 3 & Model 4 & Model 5 & Model 6 & Model 7 \\
\hline Age & $1.135 * *$ & $1.136^{* *}$ & $1.136^{* *}$ & $1.135^{* *}$ & $1.135^{* *}$ & $1.136^{* *}$ & $1.136 * *$ \\
\hline Very good health & 1.046 & 1.045 & 1.045 & 1.048 & 1.048 & 1.051 & 1.051 \\
\hline \multicolumn{8}{|l|}{$\begin{array}{l}\text { Gender typical occupation } \\
\text { (comp. Female) }\end{array}$} \\
\hline Male occupations & 1.116 & 1.125 & 1.124 & 1.113 & 1.111 & 1.143 & 1.147 \\
\hline Mixed occupations & 1.015 & 1.019 & 1.019 & 1.015 & 1.014 & 1.029 & 1.032 \\
\hline ISEI & $1.015 * *$ & $1.014 * *$ & 1.012 & $1.015 * *$ & $1.015^{* *}$ & $1.015 * *$ & $1.015^{* *}$ \\
\hline Supervisor & $1.207 * *$ & $1.201 * *$ & $1.201 * *$ & $1.184 *$ & 1.998 & $1.209 * *$ & $1.210 * *$ \\
\hline Income - highest decile & $1.236 *$ & $1.228 *$ & $1.229 *$ & $1.231^{*}$ & $1.229 *$ & & \\
\hline Income - decile (linear) & & & & & & 0.989 & $1.443 * *$ \\
\hline \multicolumn{8}{|l|}{ Country-level } \\
\hline Sex ratio in higher edu (linear) & 0.069 & 0.076 & 0.076 & 0.082 & 0.081 & 0.166 & 0.130 \\
\hline $\begin{array}{l}\text { Female labor force participa- } \\
\text { tion (LFP) }\end{array}$ & $1.037 * *$ & $1.037 * *$ & $1.036^{*}$ & $1.037 * *$ & $1.038^{* *}$ & $1.049 * *$ & $1.063 * *$ \\
\hline Cross-level interaction & & & 1.000 & & & & \\
\hline \multicolumn{8}{|l|}{ Female LFP＃ ISEI } \\
\hline Female LFP \# Supervisor & & & & & 0.993 & & \\
\hline Female LFP \# Income linear & & & & & & & $0.995 * *$ \\
\hline $\operatorname{var}(\operatorname{cons})$ & 0.146 & 0.087 & 0.087 & 0.142 & 0.142 & 0.109 & 0.119 \\
\hline $\operatorname{var}($ ISEI) & & 0.000 & 0.000 & & & & \\
\hline var(Supervisor) & & & & 0.023 & 0.019 & & \\
\hline $\operatorname{var(Income~linear)~}$ & & & & & & 0.003 & 0.001 \\
\hline BIC & 10221.2 & 10227.6 & 10236.6 & 10229.3 & 10237.8 & 10222.3 & 10222.9 \\
\hline AIC & 10143.8 & 10143.2 & 10145.1 & 10144.9 & 10146.4 & 10137.9 & 10131.4 \\
\hline Log likelihood & -5060.9 & -5059.6 & -5059.6 & -5060.4 & -5060.2 & -5056.9 & -5052.7 \\
\hline $\mathbf{N}$ & 8391 & 8391 & 8391 & 8391 & 8391 & 8391 & 8391 \\
\hline
\end{tabular}

Source: SILC 2013, N (individuals) $=8391, \mathrm{~N}$ (countries) $=27$

Likelihood-ratio tests: M2 > M1: LR chi2 $(1)=1.94$, Prob > chi2 $=0.163 ;$ M3 $>$ M2: LR chi2 $(1)=0.30$, Prob

$>$ chi2 $=0.587$; M4 > M1: LR chi2 $(1)=1.05$, Prob > chi2 $=0.305 ;$ M5 > M4: LR chi2 $(1)=0.41$, Prob $>$ chi2

$=0.520 ;$ M7 > M6: LR chi2 $(1)=7.27$, Prob $>$ chi $2=0.007$

As this table shows, a higher female employment rate encouraged homogamy. However, we did not find any support for the idea that women's occupational resources mattered less in countries with lower female labor force participation. The link between ISEI or a supervisory position and homogamy did not vary across countries. Moreover, the link between women's income and the female employment rate went in the opposite direction than it was predicted. In countries with higher female labor force participation, personal income was less important than in places with lower female labor force participation. 
Table 5: The estimated odds of hypogamy among highly educated women, cross-level interactions

\begin{tabular}{|c|c|c|c|c|c|c|}
\hline Individual level & Model 1 & Model 2 & Model 3 & Model 4 & Model 5 & Model 6 \\
\hline Age & $1.230 * *$ & $1.230 * *$ & $1.230 * *$ & $1.230^{* *}$ & $1.230^{* *}$ & $1.231 * *$ \\
\hline Very good health & $0.875 *$ & $0.875^{*}$ & $0.876^{*}$ & $0.875^{*}$ & $0.873^{*}$ & $0.873 *$ \\
\hline \multicolumn{7}{|c|}{$\begin{array}{l}\text { Gender typical occupation (comp. } \\
\text { Female) }\end{array}$} \\
\hline Male occupations & $0.612 * *$ & $0.613 * *$ & $0.613 * *$ & $0.610 * *$ & $0.616^{* *}$ & $0.621 * *$ \\
\hline Mixed occupations & $0.858 *$ & $0.858 *$ & $0.860 *$ & $0.858 *$ & $0.869 *$ & $0.869 *$ \\
\hline ISEI & 0.999 & 1.003 & 0.999 & 0.999 & 0.999 & 0.999 \\
\hline Supervisor & 1.064 & 1.064 & 1.064 & 3.411 & 1.046 & 1.049 \\
\hline \multicolumn{7}{|l|}{ Income - highest decile } \\
\hline Income - decile (linear) & $0.938 * *$ & $0.938 * *$ & $0.939 * *$ & $0.939 * *$ & $0.926 * *$ & $1.385 *$ \\
\hline \multicolumn{7}{|l|}{ Country-level } \\
\hline Sex ratio in higher edu (binary) & 1.159 & 1.159 & 1.138 & 1.141 & 1.319 & 1.284 \\
\hline $\begin{array}{l}\text { Female labor force participation } \\
\text { (LFP) }\end{array}$ & $1.035^{* *}$ & $1.037^{*}$ & $1.034 * *$ & $1.037 * *$ & $1.046^{* *}$ & $1.057 * *$ \\
\hline \multicolumn{7}{|l|}{ Cross-level interaction } \\
\hline Female LFP \# ISEI & & 1.000 & & & & \\
\hline Female LFP \# Supervisor & & & & 0.984 & & \\
\hline Female LFP \# Income linear & & & & & & $0.994 * *$ \\
\hline $\operatorname{var}(\operatorname{cons})$ & 0.073 & 0.071 & 0.164 & 0.164 & 0.234 & 0.227 \\
\hline $\operatorname{var}($ ISEI $)$ & 0.000 & 0.000 & & & & \\
\hline var(Supervisor) & & & 0.035 & 0.022 & & \\
\hline var(Income linear) & & & & & 0.004 & 0.003 \\
\hline BIC & 6766.3 & 6774.8 & 6770.3 & 6776.9 & 6757.8 & 6759.9 \\
\hline AIC & 6687.1 & 6689.0 & 6691.0 & 6691.1 & 6678.6 & 6674.1 \\
\hline Log likelihood & -3331.5 & -3331.5 & -3333.5 & -3332.6 & -3327.3 & -3324.0 \\
\hline $\mathbf{N}$ & 5449 & 5449 & 5449 & 5449 & 5449 & 5449 \\
\hline
\end{tabular}

Source: SILC 2013, N (individuals) $=5449, \mathrm{~N}($ countries $)=27$

Finally, Table 5 tests the idea that the reluctance to marry down was stronger in countries with lower female labor force participation. This hypothesis was confirmed as the odds of hypogamy were higher in countries with higher female labor force participation. One percent increase in the female employment rate was linked to an approximately 3 percent increase in the odds of hypogamy (see Model 1 in Table 5). This means that in countries where women were more likely to work and earn their own income, they were more willing to accept a partner with lower education. Models $2-4$ showed that this tendency held across socioeconomic status and positions (the interactions between female labor force participation and ISEI/supervisory position were not significant). However, the effect was slightly weaker for women with higher incomes. In other words, even if women were more likely to partner down in countries with higher labor force participation, this did not hold for high-income women. 
These women were less likely to accept a man with lower education in all countries.

\section{Conclusions}

The paper explores the question of who forms homogamous unions in the youngest cohorts in which women outnumber men in higher education, who marries down, and who postpones union formation and stays single. For most of the $20^{\text {th }}$ century, homogamy (educational similarity) or female hypergamy (women marrying up) was a dominant and normatively accepted pattern of educational assortative mating. Yet, the growing female advantage in higher education implies a major departure from this traditional pattern.

In general, there is no evidence of increasing singleness among younger cohorts. Young highly educated women are rather more likely to partner with a less educated man (Esteve et al. 2012; Esteve et al. 2013; Van Bavel 2012). In fact, women are more likely to marry down than to marry up in the youngest cohorts (Esteve et al. 2012). At the same time, the existing empirical studies show that the link between female hypogamy and some negative outcomes (e.g. divorce) is weakening (Schwartz - Han 2014). This would suggest that as women are gaining an increasing advantage in higher education, female hypogamy gets normalized.

In theory, such a change could transform gender relationships in society in general. In support of this hypothesis, data from European countries show that women are more likely to be the main breadwinners if they partner with a man who has a lower level of education than themselves (Klesment - Van Bavel 2017). However, highly educated women constitute a highly stratified group (Altonji et al. 2016). If higher resource women marry highly educated men and women with fewer economic resources partner down, it might contribute to increasing social inequality.

Unlike most of the studies on educational homogamy, we did not employ log-linear models as we were not interested in the levels of homogamy or hypogamy. Our goal was to find out whether and how the choice between homogamy, hypogamy, and singleness is linked to women's resources. Our study is built on the fundamental premise of the marriage market perspective that higher-quality individuals are able to mate with a higher quality partner (Becker 1993). At the same time, we worked with the assumption that the labor market position is the major factor determining an individual's 'value' at the marriage market (Schwartz 2010, 2013). More resources also provide more means to avoid undesirable union (Dykstra - Poortman 2010).

The analysis of the EU-SILC 2013 data confirms our hypotheses and shows that women with better jobs have higher odds of living in a homogamous union with highly educated men. Our data also show that if high resource women do 
not live with highly educated men, they are less likely to marry down compared to women with fewer resources. This result is fully in line with some previous studies (Dykstra - Poortman 2010). This finding might have important implications for the level of social inequality in society. Some authors have suggested that the growing female hypogamy might make society more equal and for example, offset a motherhood penalty (Klesment - Van Bavel 2015). Yet, it is also possible that the increase in female hypogamy might provide disproportional advantages to some households. If it is not enough for a woman to have a tertiary degree to marry a highly educated man and additional resources are needed (e.g. good job and high income), it might produce a second layer of stratification within the group of highly educated women.

As for the feminization of the occupation, the advantage of women in the male-dominated professions is fully explained by their personal resources (income and occupational status). In contrast, the higher likelihood of marrying down than staying single for women in the female-dominated fields stay even if personal resources are controlled for. Here, we invoke Van Bavel's (2010) study showing that women in the female-typical occupations are less likely to postpone a union and childbearing. He interprets the finding as evidence for their higher family orientation. It is also in line with some other studies showing that the field of education plays a major role in women's family behavior (Begall - Mills 2012).

In the end, we need to acknowledge that our study has also some limits. They should be addressed in future research. First, we do not have any attitudinal data. Thus, we cannot say how important it is for these women to find a highly educated partner. Using some other data sources, we assume that highly educated women tend to prefer highly educated men and that partnership is more preferred than singleness. However, we cannot control for such wishes and attitudes directly. Second, even though some of the predictors tend to be relatively stable others might have changed after the union formation. For example, we can assume that highly educated women tend to have a stable profession reflecting the field they graduated from. On the other hand, it is plausible that their income is not only a predictor but also a consequence of their conjugal situation. Thus, we should not causally interpret these results.

Dana Hamplová is a professor of sociology working at the Institute of Sociology, Czech Academy of Sciences. Her research focuses on social stratification, family behaviors, health and values, and religion. She authored or co-authored a number of books and her works are published in the top journal of the field such as Demography, Journal of Happiness Studies, or Journal of Family Issues. 


\section{REFERENCES}

AKERS, D. S., 1967: On Measuring the Marriage Squeeze. Demography 4(2): $907-$ 924. doi.org/10.2307/2060328

ALTONJI, J. G. - ARCIDIACONO, P. - MAUREL, A., 2016: The Analysis of Field Choice in College and Graduate School: Determinants and Wage Effects. Pp. 305396 in Handbook of the Economics of Education: Elsevier. doi.org/10.1016/B9780-444-63459-7.00007-5

ANÝŽOVÁ, P., 2018: Liší se vzdělanostní skupiny v hodnotových orientacích? Pp. 137-152. In: D. Hamplová and T. Katrňák (eds.): Na vzdělání záleží: jak vzdělanostní rozdíly ovlivňují osudy lidí v české společnosti. Brno: CDK.

BAGAVOS, C., 2010: Education and Childlessness: The Relationship between Educational Field, Educational Level, Employment and Childlessness Among Greek Women Born in 1955-1959. Vienna Yearbook of Population Research: 5175. doi.org/10.1553/populationyearbook2010s51

BECKER, G., 1993: A Treatise on the Family. Cambridge: Harvard University Press.

BECKER, G. S., 1973: A Theory of Marriage: Part I. The Journal of Political Economy 81(4): 813-846.

BECKER, G. S., 1996: A Treatise on the Family. Cambridge (MA, USA), London: Harvard University Press.

BEGALL, K.. H. - MILLS, M. C., 2012: The Influence of Educational Field, Occupation, and Occupational Sex Segregation on Fertility in the Netherlands. European sociological review 29(4): 720-742. doi.org/10.1093/esr/jcs051

BLAU, F. D. - BRUMMUND, P. - LIU, A. Y-H., 2013: Trends in Occupational Segregation by Gender 1970 - 2009: Adjusting for the Impact of Changes in the Occupational Coding System. Demography 50(2): 471-492. doi.org/10.1007/s13524-012-0151-7

BLOSSFELD, H.-P., 2009: Educational Assortative Marriage in Comparative Perspective. Annual Review of Sociology 35(August): 513-530. doi.org/10.1146/annurev-soc-070308-115913

BLOSSFELD, H.-P. - TIMM, A., 2003: Educational Systems as Marriage Markets in Modern Societies: A Conceptual Framework. In: H.-P. Blossfeld and A. T. Dordrecht (eds.): Kluwer Academic Publisher. Pp. 1-18.

COLTRANE, S., 2000: Research on Household Labor: Modeling and Measuring the Social Embeddedness of Routine Family Work. Journal of Marriage and Family 62(4): 1208-1233. doi.org/10.1111/j.1741-3737.2000.01208.x

De HAUW, Y. A. G. - Van BAVEL, J., 2015: The Shifting Gender Balance in Higher Education and Assortative Mating in Europe. Annual meeting of Population Association of America. San Diego.

De HAUW, Y. A. G. - Van BAVEL, J., 2017. The Reversed Gender Gap in Education and Assortative Mating in Europe. European Journal of Population 33(4): 1-30. doi.org/10.1007/s10680-016-9407-z

DiMAGGIO, P. - MOHR, J., 1985: Cultural Capital, Educational Attainment, and Marital Selection. American Journal of Sociology 90(6): 1231-1261.

doi.org/10.1086/228209 
DiPRETE, T. A., 2013: The Rise of Women: The Growing Gender Gap in Education and what it Means for American Schools. Russell Sage Foundation.

DYKSTRA, P. A. - POORTMAN, A-R., 2010: Economic Resources and Remaining Single: Trends over Time. European Sociological Review 26(3): 277-290. doi.org/10.1093/esr/jcp021

ESTEVE, A. - GARCÍA-ROMÁN, J. - PERMANYER, I., 2012: The Gender-Gap Reversal in Education and its Effect on Union Formation: The End of Hypergamy? Population and Development Review 38(3): 535-546.

ESTEVE, A. - MCCAA, R. - LOPEZ, L. Á., 2013: The Educational Homogamy Gap Between Married and Cohabiting Couples in Latin America. Population Research and Policy Review 32(1): 81-102. doi.org/10.1007/s11113-012-9263-4

GOTTSCHALL, J. - ANDERSON, K. - BURBANK, C. - BURCH, J - BYRNES, C. - CALLANAN, C. - CASAMENTO, N. - GARDINER, A. - GLADD, N. HARTNETT, A., 2008: The "Beauty Myth" is no Myth. Human Nature 19(2): 174188. doi.org/10.1057/9780230615595_7

GROW, A. - SCHNOR, C. - Van BAVEL, J., 2017: The Reversal of the Gender Gap in Education and Relative Divorce Risks: A Matter of Alternatives in Partner Choice? Population Studies 71(sup1): 15-34. doi.org/10.1080/00324728.2017.1371477

GROW, A. - Van BAVEL, J., 2015: Assortative Mating and the Reversal of Gender Inequality in Education in Europe: An Agent-Based Model" PLoS ONE 10(6): 124. doi.org/10.1371/journal.pone.0127806

HAMPLOVÁ, D., 2009: Educational Homogamy among Married and Unmarried Couples in Europe: Does Context Matter? Journal of Family Issues 30(1):28-52. doi.org/10.1177/0192513X08324576

HAMPLOVÁ, D. - KLÍMOVÁ CHALOUPKOVÁ, J. - TOPINKOVÁ, R., 2019: More Money, Less Housework? Relative Resources and Housework in the Czech Republic. Journal of Family Issues 40(18): 2823-2848. doi/10.1177/0192513X19864988

HAMPLOVÁ, D. - LE BOURDAIS, C., 2008: Educational Homogamy of Married and Unmarried Couples in English and French Canada. Canadian Journal of Sociology 33(4): 845-872.

HOEM, J. M. - NEYER, G. - ANDERSSON, G., 2006: Education and Childlessness: The Relationship between Educational Field, Educational Level, and Childlessness Among Swedish Women Born in 1955 - 1959. Demographic Research 14 (article 15): 331-380. doi.org/10.4054/DemRes.2006.14.15

HOU, F. - MYLES, J., 2007: The Changing Role of Education in the Marriage Market: Assortative Marriage in Canada and the United States Since the 1970s. Statistics Canada. $\quad$ https://www150.statcan.gc.ca/n1/pub/11f0019m/11f0019m2007299eng.htm

KATRŇÁK, T., 2001: Strukturální př́íčiny poklesu sňatečnosti a nárůstu svobodných v devadesátých letech v České republice. Sociologický časopis/Czech Sociological Review 37(2) :225-239. doi.org/10.13060/00380288.2001.37.2.13 
KATRŇÁK, T. - FUČÍK, P. - LUIJKX, R., 2012: The Relationship between Educational Homogamy and Educational Mobility in 29 European Countries. International Sociology 27(4): 551-573. doi.org/10.1177/0268580911423061

KLESMENT, M. - Van BAVEL, J., 2015: The Reversal of the Gender Gap in Education and Female Breadwinners in Europe. Families and Societies Working Paper Series 26. http://www.familiesandsocieties.eu/

KLESMENT, M. - Van BAVEL, J., 2017: The Reversal of the Gender Gap in Education, Motherhood, and Women as Main Earners in Europe. European Sociological Review 33(3): 465-481. doi.org/10.1093/esr/jcw063

MARE, R. D., 1991: Five Decades of Educational Assortative Mating. American Sociological Review 56(1):15-32. doi.org/10.2307/2095670

McCLINTOCK, E. A., 2014: Beauty and Status: The Illusion of Exchange in Partner Selection? American Sociological Review 79(4): 575-604. doi.org/10.1177/0003122414536391

McPHERSON, M. - SMITH-LOVIN, L. - COOK, J. M.,. 2001: Birds of a Feather: Homophily in Social Networks. Annual Review of Sociology 27 (August): 415444. doi.org/10.1146/annurev.soc.27.1.415

MONAGHAN, D., 2015: Income Inequality and Educational Assortative Mating: Evidence from the Luxembourg Income Study. Social Science Research 52 (July): 253-269. doi.org/10.1016/j.ssresearch.2015.02.001

MURPHY, E. - OESCH, D., 2016: The Feminization of Occupations and Change in Wages: A Panel Analysis of Britain, Germany, and Switzerland. Social Forces 94(3): 1221-1255. doi.org/10.1093/sf/sov099

OPPENHEIMER, V. K., 1988: A Theory of Marriage Timing. The American Journal of Sociology 94(3): 563-591. doi.org/10.1086/229030

OPPENHEIMER, V. K., 1994: Women's Rising Employment and the Future of the Family in Industrial Societies. Population and Development Review 20(2): 293342.

PERMANYER, I. - ESTEVE, A. - GARCIA, J., 2019: Decomposing Patterns of College Marital Sorting in 118 Countries: Structural Constraints Versus Assortative Mating. Social Science Research 83 (September): 102-313. 10.1016/j.ssresearch.2019.06.004

ROSENFELD, M. J., 2008: Racial, Educational and Religious Endogamy in the United States: A Comparative Historical Perspective. Social Forces 87(1): 1-31. doi.org/10.1353/sof.0.0077

SHERIDAN, J. T., 1997: The Effects of the Determinants of Women's Movement into and out of Male-Dominated Occupations on Occupational Sex Segregation. https://eric.ed.gov/?id=ED411346

SCHWARTZ, C. R., 2010: Earnings Inequality and the Changing Association between Spouses' Earnings. American Journal of Sociology 115(5): 1524-1557. doi.org/10.1086/651373

SCHWARTZ, C. R., 2013: Trends and Variation in Assortative Mating: Causes and Consequences. Annual Review of Sociology 39(1): 451-470.

doi.org/10.1146/annurev-soc-071312-145544 
SCHWARTZ, C. R. - HAN, H.,. 2014: The Reversal of the Gender Gap in Education and Trends in Marital Dissolution. American Sociological Review 79(4): 605-629. doi.org/10.1177/0003122414539682

SCHWARTZ, C. R. - MARE, R. D., 2005: Trends in Educational Assortative Marriage from 1940 to 2003. Demography 42(4): 621-646. doi.org/10.1353/dem.2005.0036

SKOPEK, J. - SCHULZ, F. - BLOSSFELD, H-P., 2010: Who Contacts whom? Educational Homophily in Online Mate Selection. European Sociological Review :jcp068-jcp068. doi.org/10.1093/esr/jcp068

SUlliVAN, O. - BILLARI, F. C. - ALTINTAS, E., 2014: Fathers' Changing Contributions to Child Care and Domestic Work in Very Low-Fertility Countries: The Effect of Education. Journal of Family Issues 35(8): 1048-1065. doi.org/10.1177/0192513X14522241

ŠETINOVÁ, M. - KLÍMOVÁ CHALOUPKOVÁ, J., 2019: Role kognitivních schopností ve výběrovém párování: partnerské preference mladých lidí. Sociologický časopis/Czech Sociological Review 55(2): 161-187. doi.org/10.13060/00380288.2019.55.2.457

ŠPROCHA, B. - DŽAMBAZOVIČ, R., 2020: Kto s kým vstupuje do manželstva na Slovensku? K niektorým aspektom výberu manželského partnera v rokoch 1992 2018. Sociologia 52(4): 374-402. doi.org/10.31577/sociologia.2020.52.4.16

TREAS, J. - TAI, T., 2016: Gender Inequality in Housework Across 20 European Nations: Lessons from Gender Stratification Theories. Sex Roles 74(11-12): 495511. doi.org/10.1007/s11199-015-0575-9

Van BAVEL, J., 2010: Choice of Study Discipline and the Postponement of Motherhood in Europe: The Impact of Expected Earnings, Gender Composition, and Family Attitudes. Demography 47(2): 439-458. doi.org/10.1353/dem.0.0108

Van BAVEL, J., 2012: The Reversal of Gender Inequality in Education, Union Formation and Fertility in Europe. Vienna Yearbook of Population Research 10: 127-154.

WOOLDRIDGE, J., 2009: Introductory Econometrics: A Modern Approach. Mason: South-Western Cengage Learning. 